\title{
Transforming manufacturing to be 'good for planet and people', through enabling lean and green thinking in small and medium-sized enterprises
}

\author{
H. T. S. Caldera ${ }^{1,2^{*}}$ D, C. Desha ${ }^{2}$ and L. Dawes ${ }^{3}$
}

\begin{abstract}
Background: The United Nations' Sustainable Development Goals remind us of the urgent need for every business to operate in ways that are good for planet and people. Manufacturing is a critical sector to address, where industry is compelled to rethink the acts of sourcing, producing, consuming and handling goods and their subsequent 'waste' components. Over the last decade in particular, lean and green thinking has emerged as a desirable strategy to improve efficiency and environmental outcomes towards sustainable business practices that meet circular economy objectives. However, moving beyond ad hoc and champion-based take-up by organisations with deep pockets, there is generally a lack of momentum towards mainstreaming such lean and green focused operations in the many small and medium-sized enterprises (SMEs) internationally. This research used case study analysis within the manufacturing sector in Queensland, Australia, to investigate how SMEs could readily engage in lean and green processes to achieve sustainable business practice with regard to the '3Ps' of the triple bottom line (i.e. Planet, Profit and People). 'Natural resource-based view theory' and 'Institutional theory' were used to develop a conceptual framework to explain the findings.

Results: The paper describes the lean and green practices observed in the SMEs, drivers for implementation, and the perceived benefits within the realm of sustainable business practice. Building on case study findings, the authors provide the first 3P Model for lean and green strategy, presenting four steps that SMEs can follow, including a 3P matrix of tools to selectively engage with lean and green actions towards sustainable business practice. This model guides SMEs to use the best tools and processes given their circumstances and aspirations.

Conclusions: The model has the immediate benefit of focusing SME time and resources towards circular economy enquiry, reducing uncertainty and enabling forward-planning. The findings provide practical guidelines to enable SMEs to achieve sustainable business practice while appreciating the 'triple bottom line' approach. The findings also have immediate policy and governance implications within the public and private sector, providing guidance on integrating lean and green thinking to advance from doing 'business as usual'.
\end{abstract}

Keywords: Sustainable business practice, Lean and green thinking, Small to medium-sized enterprises, Manufacturing efficiency, Waste

\footnotetext{
* Correspondence: savindi.caldera@qut.edu.au

${ }^{1}$ School of Earth, Environmental and Biological Sciences, Science and

Engineering Faculty, Queensland University of Technology (QUT), 2-George

Street, Brisbane, QLD 4001, Australia

${ }^{2}$ Cities Research Institute, Griffith University, 170 Kessels Road, Nathan, QLD

4111, Australia

Full list of author information is available at the end of the article
}

(c) The Author(s). 2019 Open Access This article is distributed under the terms of the Creative Commons Attribution 4.0 International License (http://creativecommons.org/licenses/by/4.0/), which permits unrestricted use, distribution, and

reproduction in any medium, provided you give appropriate credit to the original author(s) and the source, provide a link to the Creative Commons license, and indicate if changes were made. The Creative Commons Public Domain Dedication waiver (http://creativecommons.org/publicdomain/zero/1.0/) applies to the data made available in this article, unless otherwise stated. 


\section{Plain English summary}

With the increasing trends of global waste generation and environmental pollution, there are many conversations internationally around how small and medium-sized enterprises (SMEs) can become more resource efficient and reduce waste. Responding to this challenge, this research explored how manufacturing SMEs can strategically play a role in sustainable development.

Lean thinking is described as business approach that aims to deliver better value for customers by eliminating non-value-adding activities. Within this realm, conventional 'lean thinking' has expanded into 'lean and green thinking' as a targeted intervention for SMEs to reduce waste and pollution, comprising an integrated approach that focusses on resource optimisation and promotes strategies to 'do more with less'. Although a range of lean thinking tools have been shown to improve efficiency and effectiveness, they have not necessarily captured environmental and social impacts of implementation. Furthermore, considering cash flow challenges and operating budgets for SMEs, it is still unclear how to select or integrate such tools to harness best sustainable business outcomes in a cost-effective way. A 3P Model for lean and green strategy, presenting four steps that SMEs can follow, including a 3P matrix of tools to selectively engage with lean and green actions towards sustainable business practice. This model also guides SME industrial practitioners to overcome the potential for ad hoc use of lean and green tools and optimise their choice of tools - and budget expended to improve their sustainable business outcomes. Within this structure, SMEs can follow a sequence of steps to: explore, prioritise, invest, and monitor and evaluate, to transition towards sustainable business practice. Our findings are immediately useful for industry practitioners, government policymakers addressing circular economy opportunities at a firm level, and governance leaders in bridging the gap between ideas and action for scaling up sustainable business practice in SMEs.

\section{Introduction}

With the increasing trends of global waste generation and environmental pollution, there are many conversations internationally around how small and mediumsized enterprises (SMEs) can become more resource efficient and reduce waste. Responding to this challenge, this research explored how manufacturing SMEs can strategically play a role in sustainable development. The United Nations' Sustainable Development Goals (SDGs) call for direct, urgent and collaborative efforts from the industrial sector to engage in sustainable consumption and production and focus more on the triple bottom line approach of environmental, social and economic) [1], also known as the 3Ps (i.e. Planet, Profit and People). In Australia, 97\% of all businesses are SMEs [2], who commonly face challenges associated with limited financial resources, time and expertise. There is significant need for a tailored approach for this type of business to engage in sustainable business practice.

Lean thinking is described as business approach that aims to deliver better value for customers by eliminating non-value-adding activities [3]. Within this realm, conventional 'lean thinking' has expanded into 'lean and green thinking' as a targeted intervention for SMEs to reduce waste and pollution, comprising an integrated approach that focusses on resource optimisation and promotes strategies to 'do more with less' [4]. This shift of paradigm could be further explained as an advancement of doing more with the same resources and doing the same with lesser resources. Although a range of lean thinking tools have been shown to improve efficiency and effectiveness, they have not necessarily captured environmental and social impacts of implementation. Furthermore, considering cash flow challenges and operating budgets for SMEs, it is still unclear how to select or integrate such tools to harness best sustainable business outcomes in a cost-effective way.

This research evaluated how SMEs may be triggered to engage in sustainable business practice; the types of tools procured, and practices adopted; expected benefits and the potential role of lean and green thinking in sustainable business practice. Building on previous research on the co-existence of lean and green thinking, this study investigated how lean and green tools could be targeted to drive specific sustainable business practice priorities (i.e.: environmental, economic and social).

The study developed a novel 'Lean and green strategy model' for SMEs to strategically use lean and green tools, enabling them to deviate from 'business as usual' in a linear economy and contribute to the circular economy instead. This model also guides SME industrial practitioners to overcome the potential for ad hoc use of lean and green tools and optimise their choice of tools and budget expended - to improve their sustainable business outcomes. Within this structure, SMEs can follow a sequence of steps to: explore, prioritise, invest, and monitor and evaluate, to transition towards sustainable business practice.

This coupled lean and green model offers a stepping stone for SMEs to improve their sustainable business practice with regard to the 3Ps of people, planet and profit. The findings are immediately useful for industry practitioners, government policymakers addressing circular economy opportunities at a firm level, and governance leaders in bridging the gap 
between ideas and action for scaling up sustainable business practice in SMEs.

\section{Background}

Sustainable business practice is an area of increasing business interest, where organisations focus on improving process efficiencies to gain a competitive advantage. Small and medium-sized enterprises (SMEs) are estimated to contribute to nearly $70 \%$ of global industrial pollution [5, 6] triggering many conversations internationally around how this market segment can become more resource efficient and reduce waste [7, 8]. Recently this has been supplemented by unambiguous requests from the United Nations (UN) through its Sustainable Development Goals (SDG), calling for direct, urgent and collaborative efforts by the industrial sector to engage in sustainable consumption and production $[9,10]$. While UN SDGs are historically focussed on large corporations, there is a need for rapid improvement in sustainability performance by SMEs. Even though SMEs have small impacts individually, as a cluster they can have a significant cumulative impact [11] on the environment. SMEs can implement sustainable practice through substituting virgin raw materials in products with post-consumer materials, recycling and keeping resources the life cycle for a longer period of time [12]. SMEs improved sustainable business practice creates opportunities to contribute to the sustainable development goals incrementally. It is acknowledged that SMEs face unique challenges when establishing long-term actions toward sustainable development goals due to their scale, financial constraints and lack of technical knowledge. However previous research has shown that PDCA (plan-do-check-act) based management tools that can offer SMEs the opportunity to pursue sustainability in their daily practices have the potential to meaningfully contribute to United nations SDGs [13].

In the Australian market where $97 \%$ of all business are SMEs [2], they are driven by pressures from supply chain, the pursuit of cost savings and emerging regulatory requirements to engage in environmental and socially responsible practice [14]. Within this journey some SMEs adopt techniques such as cleaner production $[15,16]$ and eco-efficiency [17-20] as a foundation to establish their sustainable business practice. Lean thinking is described as a business approach that aims to deliver better value for customers by eliminating non-value-adding activities $[21,22]$. Within this realm, conventional 'lean thinking' has expanded into 'lean and green thinking' as a targeted intervention for SMEs to reduce waste and pollution [4, 23-25], comprising an integrated approach that focuses on resource optimisation and promotes activities to do more with less. This integrated approach enables SMEs to sustain in the highly competitive global market by [25] reducing lead time, improved value-added time, reducing their carbon footprint and increasing the overall production efficiency [26]. It important to note, however, that being 'lean' does not mean that an organization is 'green'. Nonetheless a lean organisation is able to induce green practices and have synergistic impact on both environmental performance [27]. This highlights the significant need for coupled lean and green practices for SMEs to choose from. SMEs must evaluate their existing level of leanness and greenness and explore opportunities to further enhance their performance through selection and adoption appropriate lean and green tools [25].

Over the years, it has been proven that lean and green practices are positively correlated $[28,29]$, mutually beneficial $[27,30]$, can be implemented sequentially or simultaneously [31] and have synergistic impact on operational and environmental performance [32]. Adopting a business strategy, such as lean and green thinking, can allow businesses to achieve bottom line savings in the production process, improve efficiency and form a platform to achieve economic sustainability [24, 27, 33-35]. Although a variety of lean tools have demonstrated positive impacts on improving efficiency and effectiveness, they have not necessarily captured environmental - or indeed social impacts of implementation [36, 37]. Furthermore, considering SMEs' cash flow and low operating budgets [38], low level of sustainability awareness [39], lack of technical know-how [40] and limited focus on sustainability as a business priority [41], it is still unclear how to select or integrate such tools to harness best sustainable business outcomes in a cost-effective way [36].

Building on previous research on exploring the role of lean thinking [24], and characterising sustainable business practice [35] this study aimed to investigate how lean and green tools could be targeted to drive particular sustainable business practice priorities, enabling SMEs to deviate from doing business as usual in a linear economy and contribute to the circular economy. Circular economy is described as whole economic system with a closed loop material flow [42] and was then extended as an economic system that is restorative and regenerative by intention and design [43].

Analysis of key literature from the last two decades highlights the emergence of lean thinking as a preferred business strategy for SMEs globally, in addition to an increasing call for manufacturing SMEs to reduce waste, improve manufacturing performance and fulfil ethical responsibility as good corporate citizens [37, 44]. This has generated a suite of lean and green tools including Value Stream Mapping, Kanban, Kaizen events, 5S, Cellular manufacturing, Single Minute Exchange of Die (SMED), Pull system, Capacity planning and Total Productive Maintenance (TPM). From this literature, the authors synthesised a suite of lean tools as they have 
been applied to key manufacturing processes, together with the documented impact on environmental performance as shown in Table 1.

Clearly lean practices that include 'green consequences' are beneficial to business operations, yet they are still underutilised within SMEs [30, 45]. This conundrum has been previously documented in 2014 by researchers [25] who concluded that lean and green tools, when combined, can form holistic and systematic models that minimise expenses and improve efficiency in business performance [37].

In order to optimise tools for different contexts, more research is required regarding the models that are currently being used. SMEs were encouraged by previous researchers [25] to position their firm's lean and green actions in a matrix so as to identify best practices. The researchers concluded that lean and green tools when combined, create structured and holistic models that can deliver operational and financial benefits [37]. These benefits can be achieved through reduced lead time, improved value-added time, reduced energy and resource consumption, reduced carbon footprint, and improved overall equipment efficiency [30].

It can be seen that there are a number of theoretical models for lean and green thinking. A stage-based theoretical model [37], model for sustainable development lean manufacturing principles [46] and model to measure sustainable practise through benchmark tools [47] are some examples for theoretical models. In addition there are empirical models such as CMMI-based Lean and Green maturity model [48], and integrated sustainable practices model [49] and, model of efficient and sustainable improvements through environmental innovation [50] that could be applied for SME contexts. The empirical cases used methods such as industrial case studies, surveys, correlation analysis and analytical hierarchy process where as the theoretical models largely used literature reviews and case studies. Through this analysis it was identified that there is a critical need for more empirical evidence and 'real-world' examples, to enable SMEs to apply the appropriate models in the future.

The literature review established a research gap of a holistic model to guide SMEs to select appropriate lean and green tools to achieve specific economic, environmental as well as social outcomes. Inspired by previous researchers' [37] recommendations to use a matrix for effectively positioning an enterprise's lean and green actions, and the authors' recent study on sustainable business characteristics [35] this paper presents the first '3P Matrix' for positioning lean and green actions, which reduces uncertainty and enables effective forward-planning in an SME operating environment.

\section{Research approach}

The study consisted of an interpretive multiple case study approach to investigate lean and green practices in SMEs, including the use of tools and models for various operations [51, 52]. Within the study, the research propositions related to: 1) how SMEs may be triggered to engage in sustainable business practice; 2) the types of tools procured and practices adopted; and 3) expected benefits and the potential role of lean and green thinking

Table 1 Lean tools in manufacturing, and their links to improved environmental performance

\begin{tabular}{|c|c|c|c|}
\hline $\begin{array}{l}\text { Lean practices related to key } \\
\text { business operations [89] }\end{array}$ & $\begin{array}{l}\text { Lean tools applied to } \\
\text { these operations }\end{array}$ & $\begin{array}{l}\text { Documented links to } \\
\text { environmental performance }\end{array}$ & $\begin{array}{l}\text { Key source } \\
\text { literature }\end{array}$ \\
\hline \multicolumn{4}{|l|}{ Process and equipment management } \\
\hline $\begin{array}{l}\text { - Minimise cycle time } \\
\text { - Reduce error through proof equipment } \\
\text { - Impalement new technologies } \\
\text { - Maintain order and cleanliness in the facility } \\
\text { - Reduce setup time } \\
\text { - Improve process efficiency and } \\
\text { prepare for maintenance }\end{array}$ & $\begin{array}{l}\text { - Value stream mapping } \\
\text { - Cellular manufacturing } \\
\text { - Kanban } \\
\text { - Autonomation } \\
\text { - } 5 S \\
\text { - Total productive maintenance } \\
\text { - Single minute exchange } \\
\text { of die (SMED) }\end{array}$ & $\begin{array}{l}\text { - Identifying environmental impacts } \\
\text { - Assessing areas to be improved } \\
\text { - Improved energy efficiency and waste } \\
\text { management }\end{array}$ & {$[46,90-98]$} \\
\hline \multicolumn{4}{|l|}{ Manufacturing and planning } \\
\hline $\begin{array}{l}\text { - Optimise production } \\
\text { - Managing of lot size } \\
\text { - Management of production } \\
\text { - Scheduling operations and maintenance } \\
\text { - Use of visual control }\end{array}$ & $\begin{array}{l}\text { - Lean layout } \\
\text { - Value stream mapping } \\
\text { - Push system } \\
\text { - Pull system } \\
\text { - Capacity planning } \\
\text { - Kanban }\end{array}$ & $\begin{array}{l}\text { - Improved waste management } \\
\text { - Improved energy efficiency }\end{array}$ & {$[92,99-103]$} \\
\hline \multicolumn{4}{|l|}{ Human resourcing } \\
\hline $\begin{array}{l}\text { - Train workers } \\
\text { - Form cross departmental team } \\
\text { - Engage employees in continuous } \\
\text { improvement initiatives } \\
\text { - Collective decision making }\end{array}$ & $\begin{array}{l}\text { - KPI } \\
\text { - Quality circles } \\
\text { - Employee engagement } \\
\text { - Kaizen events }\end{array}$ & $\begin{array}{l}\text { - Improved waste, water and } \\
\text { chemical management } \\
\text { - Improved resource productivity } \\
\text { - Improved energy efficiency }\end{array}$ & $\begin{array}{l}{[30,90,104-} \\
106]\end{array}$ \\
\hline
\end{tabular}


in sustainable business practice. The authors used an in-depth case study approach to understand the phenomena of sustainable business practice in an SME environment, through investigating their sustainable operations as the unit of analysis. The initial desktop research (literature review) helped to explore the findings of previous research and relevant theories that informed the conceptual framework and the interview protocol.

\section{Case setting and context}

Different economic systems define categories of businesses based on a variety of criteria and cluster them accordingly. In Australia, the Australian Bureau of Statistics clusters SME as an independent business entity that employ less than 200 employees notwithstanding potential diversity of experiences ranging from 1 to 2-person company through to a 200-person company. With this context this research [53] examined the nuances and opportunities for this cluster of businesses and identified an overarching opportunity for coupled lean and green tools, as well as a selection process to assist with their selection of tools and processes. This project retained the classification of SMEs used in previous research [12] to enable comparison and contrast of findings from the two case studies explored. Potential challenges with associated with these classifications and the subsequent conclusions that can be drawn are noted in discussion.

The case studies were selected through a purposive sampling approach [54], based on criteria comprising functional and suitability attributes. Functional attributes were based on geography (SMEs in South East Queensland), accessibility to the key informants, and the ability to collect data within the desired time frame. Suitability attributes were based on the number of employees in SMEs (less than 200 employees), SMEs that demonstrated leadership in sustainable business practice (i.e.: recipients of sustainability awards), and who had already established lean and green practices.

Potential case study SMEs were contacted through a professional industrial body in Queensland that aims to improve efficiency in these manufacturing firms. Lean and green thinking is well-received in large corporations, however is relatively new for SMEs and is not a mature concept within South East Queensland SMEs. Based on the selection criteria defined by the authors, there was a limited cohort of manufacturing SMEs captured within our scope. Therefore, an initial exploratory study was conducted into 13 SMEs to evaluate their existing conditions and characterize lean and green driven sustainable business practice (Caldera et al., 2018). Criteria were then defined to probe more in to these organizations and generate contextualized insights. The purpose of conducting these interpretive case studies was to draw on unique examples of SMEs modelling sustainability approaches and the resulting two case studies provide rich insights. Research on qualitative methods for social science domain notes that the new knowledge generated through in-depth evaluations of small samples can be equally valid and robust as broader evaluations of large random samples [55]. While they manufacture different products, their best practices can applied to the SME manufacturing context.

\section{Data collection}

Semi-structured interviews were used as the primary data collection method to evaluate multiple perspectives and to further explore the lean and green phenomenon [56]. Interview participants comprised Managing Directors (MDs), senior managers, and operational staff involved in sustainable and lean business practice from SMEs located in South East Queensland (Table 2). An interview guide (Additional file 1) was developed and the interview questions were based on relevant literature on lean and green approaches, SMEs, sustainable business practice, Institutional Theory and NRBV theory [57]. Prompts were used to allow further discussion during the interview process [58]. These interview questions were inspired by the possibility of SMEs being able to achieve sustainable business practice through strategic use of lean and green practice $[24,25]$. The involvement of multiple informants from three levels of the organisational hierarchy ensured the internal consistency and reliability of this study [59].

Overall 31 interviews were conducted before theoretical saturation was reached. A summary of the interviewees is presented in Table 2. The interviews were conducted for 60-90 min and were audio-recorded for transcription. A content analysis was carried out on the SMEs' websites, published reports and brochures, further contributing to data triangulation.

\section{Data analysis}

The audio recorded interviews were manually transcribed using the NVivo Pro (version 11) software [6062]. Firstly a data driven in-vivo coding was conducted through the NVivo program to develop nodes from the interview data [63]. During this coding exercise, labelling was completed using a word or a phrase elicited from the data [64]. These in-vivo codes were then grouped into axial codes where links between initial codes were identified [65]. Finally selective codes were created with links to all categories. The constant comparative method (interpretations and emergent findings were compared with existing findings) was employed to corroborate the interview findings [66]. This supported the research aims by identifying local concepts of the experience shared by the industrial practitioners related to the drivers of 
Table 2 Summary of SME participants ${ }^{\mathrm{a}}$

\begin{tabular}{|c|c|c|c|c|}
\hline $\begin{array}{l}\text { Firm } \\
\text { identifier }\end{array}$ & Industry & Participants & $\begin{array}{l}\text { Number of } \\
\text { employees }\end{array}$ & $\begin{array}{l}\text { Annual turnover } \\
\text { (million, approx) }\end{array}$ \\
\hline$\overline{F A}$ & $\begin{array}{l}\text { Paint and coatings } \\
\text { manufacturing }\end{array}$ & $\begin{array}{l}\text { FA-P1-Managing Director; FA-P2-National Sales and Marketing manager; FA-P3- } \\
\text { Operations Engineering and Technical Manager; FA-P4-Technical services officer; } \\
\text { FA-P5-Sand paper operator; FA-P6-Chemist; FA-P7-Sprayer; FA-P8-Accountant } \\
\text { receivable representative; FA-P9-Colour match maker; FA-P10-Accountant; FA- } \\
\text { P11-Accountant; FA-P12-Accountant; FA-P13-Inventory coordinator; FA-P14- } \\
\text { Receptionist; FA-P15-Lean Consultant }\end{array}$ & 70 & 26 \\
\hline$F B$ & $\begin{array}{l}\text { Fertiliser and mulch } \\
\text { manufacturing }\end{array}$ & $\begin{array}{l}\text { FB-P1-Director; FB-P2-Business development manager; FB-P3-Sales and Operations } \\
\text { Manager; FB-P4-Warehouse and production manager; FB-P5-Sales manager; FB-P6- } \\
\text { Production manager; FB-P7-Compliance Advisor; FB-P8-Health and Safety officer } \\
\text { FB-P9-Forklift Operator; FB-P10-Operator (Production); FB-P11-Forklift Operator; FB- } \\
\text { P12-Machine operator; FB-P13-Receptionist; FB-P14-Pallet controller; FB-P15-Financial } \\
\text { accountant; FB-P16-Lean Consultant }\end{array}$ & 60 & 30 \\
\hline
\end{tabular}

${ }^{\mathrm{a}} F$ Firm, FA Case study 1, FB Case study 2, $P$ Participant

sustainable business practices, and the types of tools used. The key informants reviewed the case study findings to ensure authenticity and clarity [67].

The themes within the cases were derived through a thematic analysis [68]. This was followed by a cross-case analysis to synthesise the themes that emerged across the cases structured along the elements of the conceptual framework $[59,69]$.

\section{Credibility and corroboration of findings}

This research adopted an interpretive approach and hence the analysis may be subjective and emergent in nature. Four guidelines established by several researchers were used to ensure rigour in this approach. These guidelines include 1) provide a clear chain of evidence [70], 2) consider alternative explanation, multiple viewpoints, potential biases [51], 3) corroborate findings and aim for theoretical saturation [71] and 4) aim at generalisation beyond the substantive area under investigation [51].

First, to ensure a clear chain of evidence the researchers provided a traceable, documented justification of the research process. The interviews were transcribed through the NVivo software to minimise the inaccuracies and enable open coding of data. A case study protocol was developed with an overview of the research topic [72]. The coding and analysis process was documented in excel spread sheets and the nodes were saved in a NVivo project allowing the co-researcher to trace the emergence of the codes from the interview data [63].

Secondly, to provide multiple viewpoints and corroborate findings, different data collection methods and data sources were used. Data collection methods included interviews and evaluating related documents (i.e. brochures, annual reports, and published case studies) [71]. Three researchers were engaged in coding, data analysis and conceptualisation phases to re-check to corroborate the data collected through interviews and documents analysis.

Thirdly, several actions were taken to corroborate findings, understand multiple interpretations and aim for theoretical saturation. A team of three researchers (the authors) coded the interview data to corroborate the emergent themes and to reduce bias in the synthesised data addressing inter-coder reliability [73-75]. The inter-coder reliability or inter coder agreement confirms that the coded data produced by independent coders are reliable [76]. There was a percentage agreement of $80 \%$, which is an acceptable inter-coder reliability rating [77]. The minimum of 0.70 inter coder reliability rating is recommended to ensure reliability. Previous research conducted in this domain has ranged from have had inter-coder reliability of $80-84 \%[76,78]$. The interviewing process continued until no new data arose and theoretical saturation was achieved.

Lastly, findings from the two SME case studies were broadened in their generalisability, through linking the observed unique instances to "ideas and concepts that apply to multiple situations" [51]. This included bringing in the theoretical lenses of Natural Resource-Based View (NRBV) theory and Institutional theory. Abstractions were connected directly to the case data, ensuring traceability and plausibility of our justifications and conclusions [51].

\section{A conceptual framework for analysis}

Based on the literature review findings, the authors developed a conceptual framework (Fig. 1) to guide the exploration of the two case studies, as a practical foundation to guide the empirical work [70]. Interpretive studies have a substantial degree of openness to the field data and allow for changes to initial assumptions and theories [70]. After exploring a number of theories related to sustainable business practice, theoretical concepts from Institutional Theory and NRBV Theory were incorporated into an overarching conceptual framework to examine the research findings [79], in addition to the 3P appreciation of sustainable business outcomes with regard to people, planet and profit [80].

Institutional theory explains how social structures have been established through rules and norms, where social 


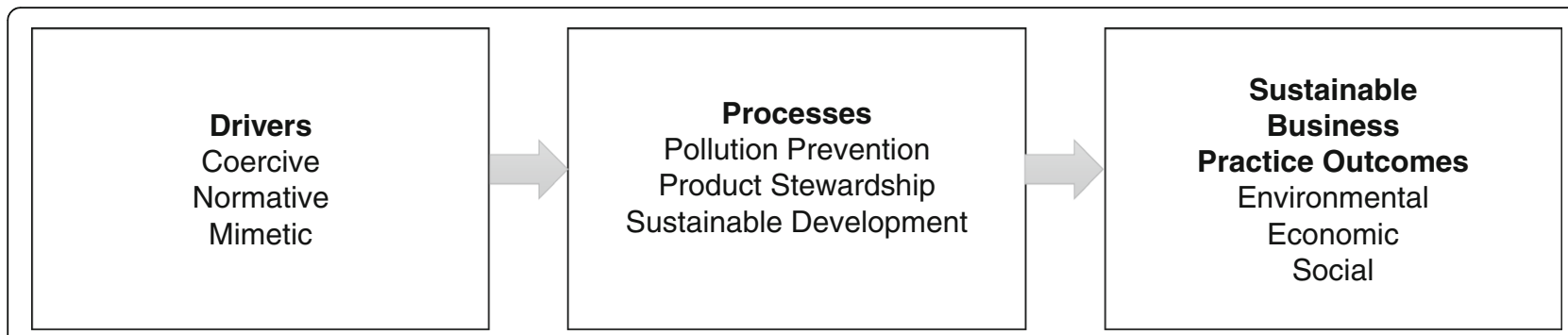

Fig. 1 Conceptual framework for exploring the two case studies

behaviour is driven through authoritative guidelines (Scott, 2004). This theory describes key concepts such as legitimacy and isomorphism. Legitimacy in a sustainable business context refers to implementing business actions that are accepted by stakeholders and comply with rules and regulations (DiMaggio and Powell, 1983; Scott, 2003). Institutional isomorphism discusses mechanisms that form social structures to achieve rationality then leads to homogeneity of structures. This isomorphic behaviour leads to the organizations to achieve legitimacy (Scott, 2004).

Drivers in Fig. 1 for engaging in lean and green thinking were categorised using mechanisms adapted from the Institutional theory [81]. Three institutional mechanisms including coercive, mimetic and normative drivers were used to describe the similar behaviour of firms in terms of institutional strategies, structure and processes. For example, coercive mechanism is described as typically occurring in the form of an influence exerted by a powerful entity, largely in the form or regulations and compliance mandated by the governing body [82]. Mimetic isomorphism takes place when organisations imitate other successful competitors in the industry to gain legitimacy. Normative isomorphism pressure is explained as professionalisation, and conforming to social obligation and thereby engaging in legitimate practice [83].

NRBV theory which is builds upon Resource Based-View (RBV), explains that a firm's ability to manage natural resources and develop capabilities to address the volatile environment will lead to competitive advantage [84]. The theory describes three inter-connected strategies of pollution prevention, product stewardship, and sustainable development, which can be implemented as a sequence or in parallel. This theory was used to provide a theoretical perspective on processes, as it is a well-established lens to explore opportunities for productivity improvement, and sustainable practice in SMEs [85].

\section{Case study findings and discussion}

The following paragraphs summarise findings from the exploration of the two South-East Queensland SMEs where eco-products are manufactured, referred to as 'Firm $\mathrm{A}^{\prime}$ (FA) and 'Firm B' (FB). In the following paragraphs, we identify eight key influences - or drivers - that can promote sustainable business practice, informing the strategy model for lean and green processes. The use of lean and green tools by the two SMEs is then discussed in relation to achieving more sustainable business practice.

\section{Profiles of the two case studies}

Firm A is an example of an architectural coating enterprise, manufacturing a range of eco-products such as paint and renders. This firm has been recognised with an award for leadership in business sustainability for proactive engagement in environmental practices. Firm A uses natural and easily-renewable resources where possible, to manufacture products catering to the needs of contemporary customers. They are also the pioneers in establishing a state-of-the-art, dry-mix render plant with high quality and environmental standards, making it the first of its type in Australia. The innovative gravitational system and modern technological standards to manufacture high quality pre-mixed, bagged cement render products enabled this SME to further focus on improving efficiency in energy, water and resource usage. They practise a 'minimum intervention model' where effective measures are taken to 'do no harm' to the environment and society.

Firm $B$ is a business that has diversified from farming enterprise to establish a value recovery process of recycling and colouring waste pallets and crates, into commercial mulch. They have previously received a business excellence award in environment and sustainability for commitment to eco-efficient management strategies. Firm B has been pioneering the collection of timber and urban waste, and the recycling of these materials to make mulch. This firm has a holistic approach to increase utilisation of urban waste that is perceived as 'wrong time and place' materials, to 'right time and place resources'. They are modelling lean and green strategic behaviours at a small-scale farming level, while also manufacturing a range of products such as premium feeder and decorative mulches, potting mixtures, growing media, sands and animal bedding. Waste material including clinker from industrial boilers are used as a sterile drainage material in potting mix blends, highlighting 
how an SME can continue to diversify and further develop lean and green strategies.

\section{Drivers promoting sustainable business practice}

As SMEs in the South-East Queensland manufacturing industry, both enterprises identified the strategic need for engaging in sustainable business practice. Through the case study analysis, the authors observed a number of drivers influencing their capacity to engage in sustainable business practice. These drivers were considered and categorised as 'normative,' 'mimetic' and 'coercive' drivers described in Institutional Theory. For example, the Operations Manager of Firm B (FB-P3) highlighted that the National Association for Sustainable Agriculture Australia (NASAA) recommends potting mixes without peat products, as invasive mining processes are extracting peat at a rate higher than it can be replenished. NASAA has a powerful position in the agricultural product manufacturing sector and have illustrated some level of coercive influence on Firm B to manufacture products without peat products.

The eight distilled drivers are shown in Table 3, including: 1) awareness and educational foundation; 2) desire to learn from industry leaders; 3) previous stewardship experiences and cultural alignment; 4) desire to deal with future uncertainty; 5) connection with government and stakeholders; 6) previous training and work experience; 7) focus on process efficiency; and 8) technological advancement. Table 3 also includes examples provided by senior decision makers of the studied SMEs, to provide qualitative evidence for the drivers within the firm's operating context. We intend that these examples encourage and enable other SMEs to understand how to drive engagement in sustainable business practice. According to Table 3, normative drivers were dominant in the observed case studies compared mimetic and coercive drivers. The coercive drivers were not prominent in the interview findings and this highlights the need for government and policy makers to engage in actions to encourage SMEs to be adopt sustainable business practice. Further, this confirmed the drivers found in literature on stakeholder engagement [86, 87], legislation and knowledge [87] and focus on streamlining processes and business direction [88]. In addition, new drivers were identified, comprising a desire to deal with future trends, societal expectations for legitimate business practice, previous training and work experience, and technological advancement.

\section{Environmental performance}

Both SMEs already engage in a variety of environmental management practices that particularly focus on waste, water, energy emissions and chemical management. Firm A was specifically demonstrating high level of natural resource usage instead of chemical synthetic material for their paint and render manufacturing. Firm B showed strong performance in resource recovery and waste management where they have diversified their business from sugar cane farming to recycled mulch manufacturing and food waste composting. A range of environmental performance outcomes were observed in the two case studies, as shown in Table 4, under the headings of waste, water, energy, chemical and emissions management (Table 4). The approaches of the two SMEs are then elaborated in the following sections with regard to environmental management, regenerative business practice, and creative innovation.

The analysis investigated the ways in which these firms integrated environmental management practices with lean methods and anticipated the cumulative benefits. With regard to environmental management, respondents from both SMEs related to the need to integrate: "Lean and green thinking is an interesting marriage of philosophies. These lean and green practices have really helped us to improve our environmental performance" (FA-P1). Firm A believed $5 \mathrm{~S}$ is a fundamental tool to create a clean and neat environment, as well as reduce unwanted raw materials, overproduction, and instruments lying around the factory premises. "If we look at the lean toolbox, $5 S$ is everybody's start point. As far as environmental management is concerned that really comes out from a $5 S$ approach. Simply because $5 S$ is considered as a housekeeping tool rather than anything else. But for lean and green practice, this is just the beginning only because it starts to form a structure where people can follow" (FA-P2), "It's the best tool we could have" (FB-P3). The use of $5 \mathrm{~S}$ is followed by the use of the PDCA (Plan-Do-Check-Act) cycle, which aims for continuously improve the organizational practices, and "Allows people to plan, do, check and act. I even started using the Deming cycle, which is study instead of check" (FA-P3).

Both Firm A and B used the tool of Process Mapping (PM) to draw the workflow diagram, to clearly understand their manufacturing processes. Value Stream Mapping (VSM) was then used to further visualise the manufacturing process and identify bottle necks, extra lead times and non-value-added activities. This tool clearly overlaps with environmental management, as it enables the user to determine environmental impacts in the manufacturing process and improves environmental performance through reducing scrap material and defects.

Sustainable-Value Stream Mapping (Sus-VSM) was used by Firm A, using integrated resource, energy and emission matrices to reduce waste by showing the times and points of waste generation: "Halfway through a process where people start looking at it, why are we doing this? We have to keep them focussed till the end. So, we need to start with the process map and go to value 
Table 3 Identified drivers and examples of sustainable business practice

\begin{tabular}{|c|c|c|}
\hline Identified drivers & Firm A senior decision maker examples & Firm B senior decision maker examples \\
\hline \multicolumn{3}{|c|}{ Self-awareness and learning from industrial experts, popular philosophers in order to be perceived as a legitimate business } \\
\hline $\begin{array}{l}\text { Awareness and educational } \\
\text { foundation }\end{array}$ & $\begin{array}{l}\text { "Mostly I educated myself. It's an outbreak of being } \\
\text { interested in the ideas of Edwards Deming and Peter } \\
\text { Singh from the Fifth discipline. Then more specifically } \\
\text { I suppose the way to do things was well described by } \\
\text { Hunter Lovins in Natural Capitalism." (FA-P1) }\end{array}$ & $\begin{array}{l}\text { "We are working with universities (which) legitimises } \\
\text { and formalises the process. We have been } \\
\text { collaborating with the universities for testing } \\
\text { processes. So just probably triggers, what comes out } \\
\text { of the informal conversation we have and what we } \\
\text { do? And that probably is some help in doing things } \\
\text { right. It's been a help to formalise our ideas. And see } \\
\text { whether we could get some marketing benefits and } \\
\text { innovating new spaces." (FB-P3) }\end{array}$ \\
\hline
\end{tabular}

a Learn and replicate to establish legitimate business practice

Desire to learn from industry "People like Ray Anderson from Interface - we learned leaders best practices from them." (FA-P1)

"There was an aluminum company that we learned best practices from. And it was driven by their top management" (FB-P4)

a Understand the future trends in ecological principles, and understand the societal expectations for legitimate practice

Previous stewardship experiences and cultural alignment

"What we have developed though the business is healthy products, we call it re-seek and develop. We look backwards we find out what people used to do, and we try and develop that into allowing us to use it in the modern days. So there are components within our materials that are modern day components, science has advanced to a point where we could utilise some of these things and still create relatively natural products" (FA-P3)

aLearn and replicate to establish legitimate business practice

Desire to deal with future trends, societal expectations for legitimate business practice
"We are about thriving and about health. If we can make a healthy environment. That's how we want it to be. Not to make it sustainable the way that it is now. We are not adding anything, we are not taking away anything. More like regenerative business practice". (FA-P1)

"When our organisation begin the journey they triggered, as the family sort of come from a farming background and have been in the stewardship journey - as farmers they are good stewards of the land. Looking after the soil and putting back whenever they could. They used to farm certified sugar cane and a lot of different things, like manures and stuff like that, instead of using chemical fertilisers" (FB-P3)

"With the 40 different types of insects, pathogens coming inside to the country, the amount of material exported around the world should be controlled. What we can control is what's coming inside our site. Bad outbreaks and different things. That's about preparing the company for what comes next." (P3), "Social media has a very influential group for people who comments on our products and so we have to cater to their expectations and demands" (FB-P3)

a Influenced by powerful positions such as government and other governmental bodies to adopt legitimate business practice

Connection with

Government and stakeholders
"We used to have a monthly tour of the design centre. Through Eco Biz-Manufacturer's networking. We have shown a lot of people. There has been a lot a of interest from people. They sort of got involved with their job from the government to help other business to become more sustainable and they use us like a flagship for some extent" (FA-P2)
"There was a federal government program in which they looked at our business practices and identified areas for improvement and made recommendation as to what sort of things we could do to improve business practices. That was really helpful and all the recommendations they made were around continual improvement and efficiency in the business." (FB-P3)
Mimetic

Normative

Normative

Coercive, Normative

a Inter-hiring between firms of the similar industry encourages isomorphism and transfer of legitimate professional practices

Previous training and work "I've been in this field for 15 years; that inspired me to experience

transfer that learning to this workplace from my earlier job" (FA-P3)
"We hired a new production manager from a renowned company, which is known to have high standard business practice." (FB-P2)

a Learn and replicate, understand the societal expectations and establish legitimate business practice

Focus on process efficiency

"I always look at our process and think how we could make it more efficient. I think of what people will gain from our practices and how it will affect the quality of our work." (FA-P3)
"Going forward the world we will be living in, it's going to get harder and harder to get a competitive price. We have to look at our cost base. We are currently okay, but we have to produce more with the same number of people at a lower cost. For that we have to look for more efficient and sustainable solutions" (FB-P4)

aLearn and replicate, to understand the societal expectations and establish legitimate business practice

Technological advancement "Our dry plant was built with a lot of lean principles built into it. Quality is already in it. The speed, efficiency of the machinery - what comes out no
"We use drone technology to take aerial photographs Normative, of the stock piles and remove unnecessary waste. For Mimetic example, the stuff about anaerobic digestion,
Normative, Mimetic
Mimetic

\section{Related}

Normative

e


Table 3 Identified drivers and examples of sustainable business practice (Continued)

\begin{tabular}{lll}
\hline Identified drivers & Firm A senior decision maker examples & Firm B senior decision maker examples \\
\hline one touches anything harmful, it's palletized by a & $\begin{array}{l}\text { Remething to do with compost wind row turning } \\
\text { driver/s }\end{array}$ \\
robot- mixed by a computer and bag. People don't & $\begin{array}{l}\text { technology that we purchased, to do with other } \\
\text { touch }\end{array}$ \\
There is only a little thing to do make it better faster poutive projects we've got going on. It's good if & $\begin{array}{l}\text { you have a champion, like myself like our business } \\
\text { and easier" (FA-P4) }\end{array}$ & $\begin{array}{l}\text { and productions managers, we are in leadership } \\
\text { positions to explore the use of new technologies." } \\
\text { (FB-P2) }\end{array}$
\end{tabular}

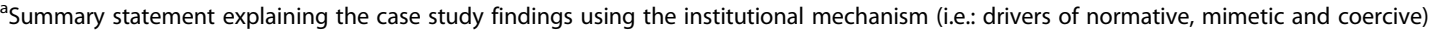

stream map" (FA-P3). Firm B utilised Four Fields Mapping (FFM) in conjunction with Sus-VSM while coordinating with team members, phases, tasks and standards. This is a clear example of overlapping areas of lean and green thinking in the potential integration of lean and green tools when aiming for sustainable business practice. These practices co-exist with the first NRBV strategy of pollution prevention and helped Firm B to identify waste in their manufacturing process, which could then be re-used as an erosion blanket.

Both firms used creative innovation to find innovative solutions that reduce impact on the environment while, at the same time, improve efficiency and productivity in the manufacturing process. For example, FA-P4 highlighted how the inspiration of nature led to the development of a range of natural products including natural lime, clay and straw bales, all of which have a low embodied energy, as a strategy that contributes to the second NRBV strategy of product stewardship: "Biomimicry is the gold standard, we are looking at our clay building products and we look at how nature builds things. In nature, swallows use clay, bees use wax. We can get an inspiration from natural materials and use them".

With regard to regenerative business practice, both SMEs highlighted the need to advance sustainable business practice and to be more engaged with restoring and creating a healthy ecosystem, as reflected by FA-P1: "We focus on designing a healthy and a liveable environment for people", and FB-P3: "We are regenerating, without burning or landfilling the waste we make mulch out of it to improve the soil conditions in landscape yards".

\section{Economic performance}

A large number of tools were acknowledged by respondents across the two SMEs as shown in Table 5. Tools such as capacity planning, quality circles, lean culture, pull approach, lean supply chain management, Just-In-Time (JIT), inventory reduction, maintenance of buffer level, 5S, Total Productive Maintenance (TPM), Value Stream Mapping was observed in both SMEs. A range of economic outcomes are discussed in the following paragraphs, under the strategic work streams of integrated vision, process efficiency and effectiveness and risk assessment. Respondents across both SMEs discussed journeys of incremental change through incorporate lean practices to minimise waste and increase efficiency in manufacturing processes. By using lean tools such as automation, JIT, Kaizen, and Value stream mapping, SMEs can improve their economic performance. For example, the business development manager in Firm B stated, "We use JIT for producing different coloured mulch and continue to supply to our customer demands on time". The production manager added by stating, "In true Kaizen sense we get a cross section of a team to design purposeful steps for better performance." These lean tools were used to reduce the lead time, unblock bottle necks and eliminate non-value adding activities which has positive impact on their bottom-line savings and economic

Table 4 Environmental performance across the two case study SMEs

\begin{tabular}{|c|c|c|c|c|c|}
\hline \multirow{2}{*}{$\begin{array}{l}\text { Firm } \\
\text { Identifier }\end{array}$} & \multicolumn{5}{|c|}{ Environmental Performance Management Areas } \\
\hline & Waste & Water & Energy & Emissions & Chemical \\
\hline$\overline{F A}$ & $\begin{array}{l}\text { - Utilise bio-based } \\
\text { material for paint } \\
\text { and render production } \\
\text { - Segregate waste } \\
\text { - Recycle waste }\end{array}$ & $\begin{array}{l}\text { - Harvest rain water } \\
\text { using tanks } \\
\text { - Use water efficient } \\
\text { appliances in toilets }\end{array}$ & $\begin{array}{l}\text { - Use of natural } \\
\text { lighting, sensors } \\
\text { and energy } \\
\text { efficient } \\
\text { appliances } \\
\text { - Thermal Dry Zone } \\
\text { Walling System }\end{array}$ & $\begin{array}{l}\text { - Use efficient filtering } \\
\text { functions } \\
\text { - Use energy efficient } \\
\text { appliances in the factory } \\
\text { and the administration } \\
\text { building }\end{array}$ & $\begin{array}{l}\text { - Use of lime, clay } \\
\text { and other natural } \\
\text { material as } \\
\text { substitutes to } \\
\text { chemical/ synthetic } \\
\text { raw material } \\
\text { - Reduce the use } \\
\text { of VOC }\end{array}$ \\
\hline FB & $\begin{array}{l}\text { - Recycle organic and } \\
\text { green waste } \\
\text { - Recover food waste to } \\
\text { produce compost }\end{array}$ & $\begin{array}{l}\text { - On-site water management } \\
\text { system through water recycling } \\
\text { (i.e.: use of a damn to store water) }\end{array}$ & $\begin{array}{l}\text { - Energy efficient } \\
\text { grinding machine }\end{array}$ & $\begin{array}{l}\text { - Reduce emissions by } \\
\text { using energy efficient } \\
\text { machineries for } \\
\text { grinding, mixing and turning }\end{array}$ & $\begin{array}{l}\text { - Use of organic } \\
\text { materials }\end{array}$ \\
\hline
\end{tabular}




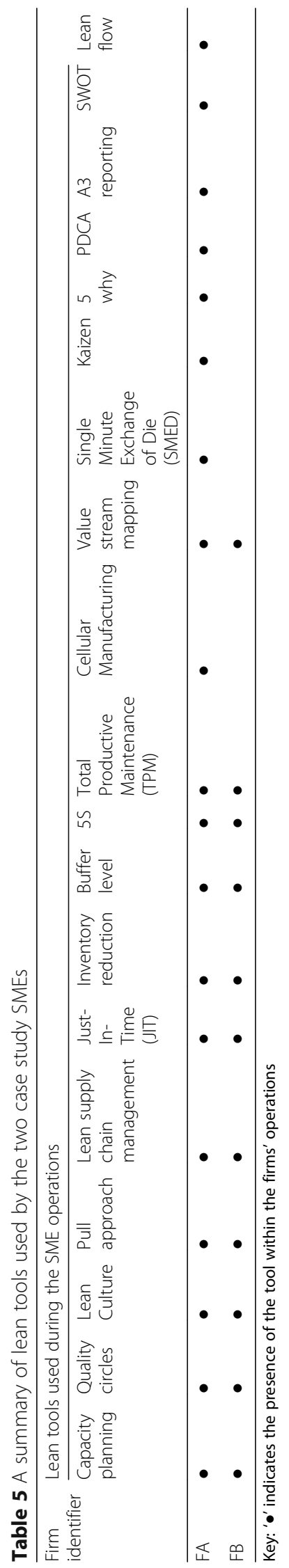


performance in these SMEs. Table 5 shows a summary of lean tools used by the two SMEs to improve their process efficiency and increase profitability.

Firm A appeared to value the use of lean and green practices to reduce employee workload, while maintaining process efficiency through eliminating non-value adding activities. This was made explicit by participant 3 of Firm A, who commented, "Through eliminating non-value adding areas after visualising the process, actually there is less work for employees. So I'm asking them to do less work and produce more". The lean flow also significantly reduced unnecessary motions and have created a sequence of production going beyond departmental boundaries in Firm A. The defined key performance indicators have created a structured methodology in the SMEs with the area targets and indicators to monitor. For example, "KPIs really help our employees to have a clear idea of what they have to work for. Simple KPIs make this process work" (FB-P4).

Firm A practised integrated lean and green thinking by using bio-degradable bags and an efficient pull system as illustrated by the following example. Participant 3 in Firm A reflected specifically on the need to ensure information and material is pulled based on customer demand, "We are fairly good at inventory reduction and pull system. We have very little products that sits around a very long time. Our packaging material is bio-degradable. It's recyclable, compostable. We make sure our product packaging breaks down wherever it ends up even if it's landfilled or recycled". They also addressed the common waste handling issue of packaging material going into landfill by taking mitigation measures of packaging products in bio-degradable bags. Together with pull system and using bio-degradable bags, the SME was able to achieve performance improvements in both economic and environmental areas. Firm A highlighted the importance of risk profiling using tools such as SWOT and 5 Why, to evaluate the level of risk, when investing in a sustainable business initiative to give internal and external factors (FA-P1). "I would use SWOT. It gives you both internal and external points. We also use five whys as a system to get people to think and get down to that lowest common denominator." The iterative approach of always asking why by using 5 Why tools, has appears to have supported Firm A to cultivate lean culture proactive attitude. Both enterprises strategically engaged with lean and green tools in the work areas of integrated vision, process efficiency and effectiveness, and risk assessment.

\section{Social performance}

Interviewees from both SMEs expressed how their enterprise was governed by unique values and beliefs but still needed a structure to support measurable, explicit social outcomes. Table 6 presents a number of social-cultural activities observed in SMEs. Firm A embedded the 'do no harm to the environment' phrase into their business culture, in addition to embedding ongoing education and awareness. Among these activities providing freedom in decision making and testing new ideas was a highlight in Firm A. Organisational freedom was claimed as a key approach used in Firm A to facilitate sustainable practice. "It's part of the organisational freedom that we are moving towards and helping people to be sustainable. We are modelling on the re-inventing organisation, which is an organisation freedom methodology by Frederic Laloux" (FA-P1).

The SME participants also highlighted conducting strategic meetings, and clearly communicating the key messages regarding the correct implementation of lean and green tools were powerful in increasing awareness on why lean and green thinking is critical in driving sustainable business practice.

Furthermore, both SMEs considered consulting external experts, relevant government professionals and academics as a key move for them to learn about best practices and advance from doing 'business as usual'. For example, Firm A was engaged in community restoration activities after a natural disaster in their areas and supported renovations of houses affected. This was aligned with their outward social action and corporate social responsibility agenda. They also commented on previous research enquiry with 'The Natural Edge Project' research team (Urban Research Program, Griffith University), demonstrating a longer-term engagement with research and education. Firm B commented on engagement with government professional bodies such as 'Citysmart' and local councils to develop socially acceptable and sustainable recycling practices. Firm B also continues to work with three universities and support their research projects to advance the evidence base on sustainable manufacturing practices, and strategies to close the loop. They are involved with local councils to develop a food waste monitoring tool and to reduce the odour issues in the social environments and provide solutions to reduce the waste going into landfills. Engaging with these networks appears to have supported both firms to contribute to the mainstreaming of sustainable business practice in South east Queensland.

By providing ongoing training, key SMEs can engage employees and encourage their participation in lean and green-driven sustainable business practice. For example, "Training is more about understanding and doing; if people understand the why, the reasons behind doing things, it makes a whole lot more sense to them" (FA-P3). However, it is only by integrating all environmental, economic and social outcomes that SMEs can move toward sustainable development, which is the third strategy of the NRBV theory. 
Table 6 Observed social-cultural activities in the two case study SMEs

\begin{tabular}{lc}
\hline Observed social- cultural activities within the two SME case studies & $\frac{\text { Firm identifier }}{\text { F-A }}$ \\
\hline Internal & F-B \\
Increasing sustainability awareness across all departments and functions & $\bullet$ \\
Providing freedom in decision making and testing new ideas & $\bullet$ \\
Encouraging employees to engage in deep work & $\bullet$ \\
Implementing clearly defined communication channels & $\bullet$ \\
External & $\bullet$ \\
Community engagement and Corporate social responsibility & $\bullet$ \\
Surticipating in events with networking opportunities such as industry conferences, conventions and workshops \\
Conducting stakeholder consultation and engagement activities
\end{tabular}

\section{A model for engaging in lean and green thinking}

To overcome the potential for ad hoc use of lean and green tools currently observed in many SMEs in South East Queensland [35], the authors have developed an emergent 'Lean and green strategy model' (Fig. 2), including a 3P Matrix, as a useful guide for SMEs to engage the best tools and processes for their circumstances and aspirations, to improve their sustainable business outcomes. Within this structure, SMEs can follow four steps to: 1) explore, 2) prioritise, 3) invest, and 4) monitor and evaluate, to support the strategic selection of tools in their transition towards sustainable business practice, as discussed in the following paragraphs.

\section{Step 1. Explore the existing context}

Firstly, the SMEs need to explore the existing context of business operations. This exercise will enable SMEs to identify the high performing areas and opportunities for further improvement. For example, a SME may have a vision of becoming economically sustainable (i.e.: through improving efficiency, productivity and reducing lead time) as well as environmentally sustainable, however remain unclear on the type of tools they could use to optimise their environmental outcomes. Through the case studies it was evident that the industrial practitioners who are in need for continuous improvement constantly explores and evaluates their current processes. For example, respondent FA-P3 noted, "I always look at our process and think how we could make it more efficient. I think of what people will gain from our practices and how it will affect the quality of our work.".

Within environmental management, SMEs could decide which aspect (i.e. energy, water or chemicals management) they seek to improve further before conducting a self-evaluation of their business practices to identify the opportunities for improvement available within their processes. They could further establish interest in learning new techniques to achieve sustainable business practice. For example, FB-P2 noted, "We researched and found there might be something to be used as an erosion barrier, within our lean flow. Different types of opportunities coming out of these types of exercises".

In summary, SMEs could align opportunities for improvement to do more with less. In actioning the SME commitment, the subsequent model steps then enable SMEs to attain resource efficiency objectives, reduce pollution and keep resources in the life cycle for longer.

\section{Step 2. Prioritise the most critical performance improvement areas}

Secondly, SMEs could prioritise the most critical performance improvement areas out of environmental, economic and social areas. They could assess their business objectives, vision, mission and the targets to prioritise the types of work streams. In the case studies, SMEs used tools such as quality circles to reflect on critical areas, value adding and non-value adding activities. Quality circles enabled the industrial practitioners to generate new lean and green process solutions for SMEs to be more environmentally sustainable, as reflected by FB-P2 comment, "Once we identify the value adding and non-value not adding activities, the team will come up some ideas of why don't we put these things there and some other stuff somewhere else and make a new product out of waste". This exercise then led develop new ideas for opportunities to improve business performance. For example, Firm B prioritised critical performance area to be reducing 'muda' (waste) and waste management using a waste product of one process as a raw material for another. This practice also catalysed this company to shift its business agenda and diversify their agricultural products.

Firm B prioritised this phase of the manufacturing process and also prioritised technological advancement 


\section{Explore the existing context of business operations}

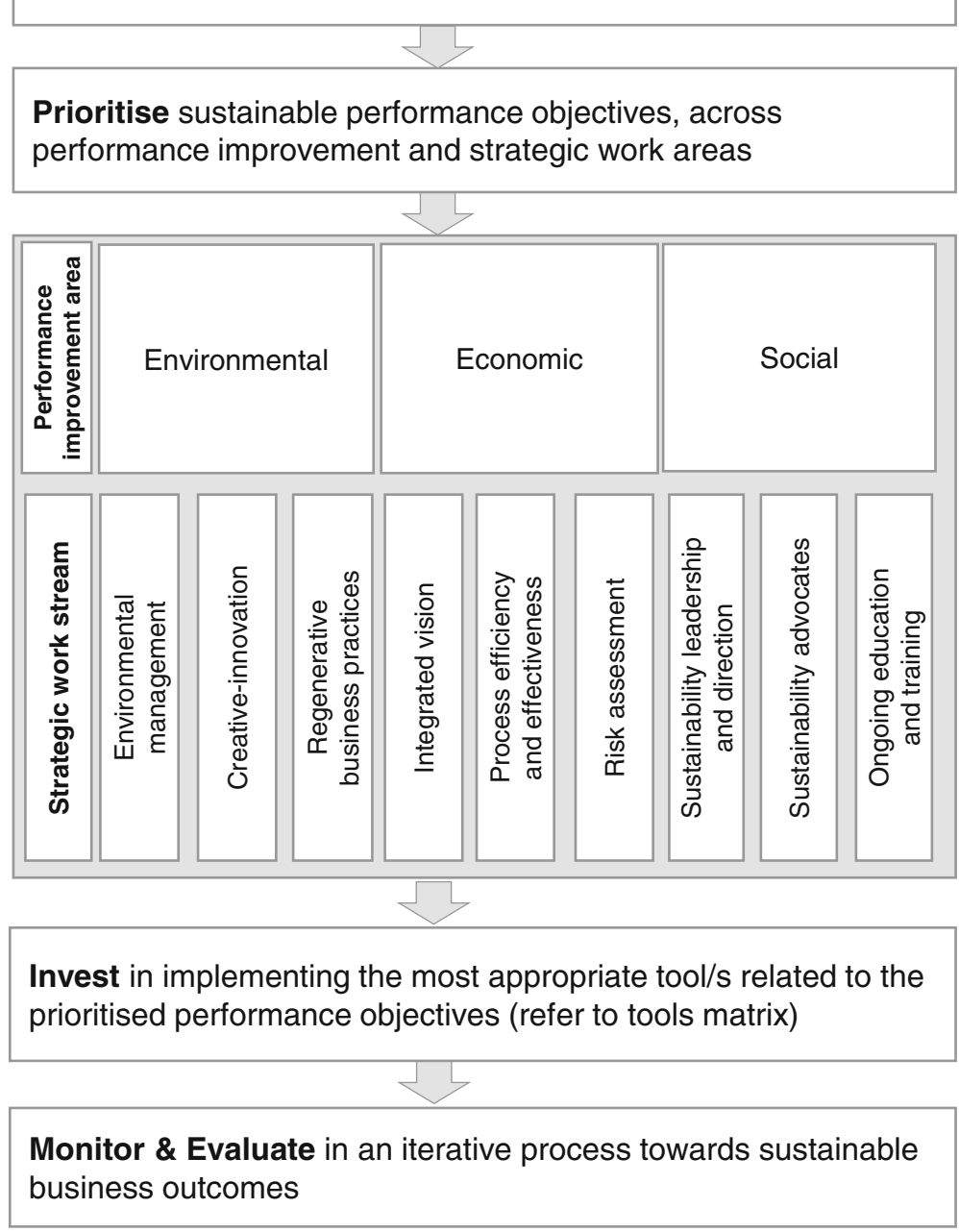

Fig. 2 Emergent lean and green strategy model for performance improvement

of automating the coir fibre hydrating process though automation. For example FB-P6 noted, "With our coconut fibre product, we have a manual way of hydrating coir fibre, we are looking at upgrade of that process and automate it. They'll break up coir fibres and hydrate it automatically".

In exploring critical performance improvement areas, SMEs can consider opportunities to align core business functions with the following streams:

- People: Sustainability leadership and direction, Sustainability advocate, Ongoing education and training

- Planet: Environmental management, Creativeinnovation, Regenerative business practice

- Profit: Integrated vision, Process efficiency and effectiveness, Risk assessment,
This initial analysis will aid the SMEs to find strategy-action gaps and then developing measures to capitalise on the performance improvement opportunities to close the gap. With considerations of business trends in the external environment, the SMEs can equip themselves with appropriate tools to remain competitive in the market.

\section{Step 3. Invest in the most appropriate tools}

The third step involves investing in the most appropriate tools related to the prioritised performance objective by referring to the associated $3 \mathrm{P}$ matrix presented (Table 7). Table 7 offers the first 3P Matrix tailored for SMEs to position their lean and green actions and identify tools which can offer multiple benefits across the streams described in Step 2. The SMEs conduct a cost benefit 
Table 7 3P Matrix for performance improvement towards lean and green business practice

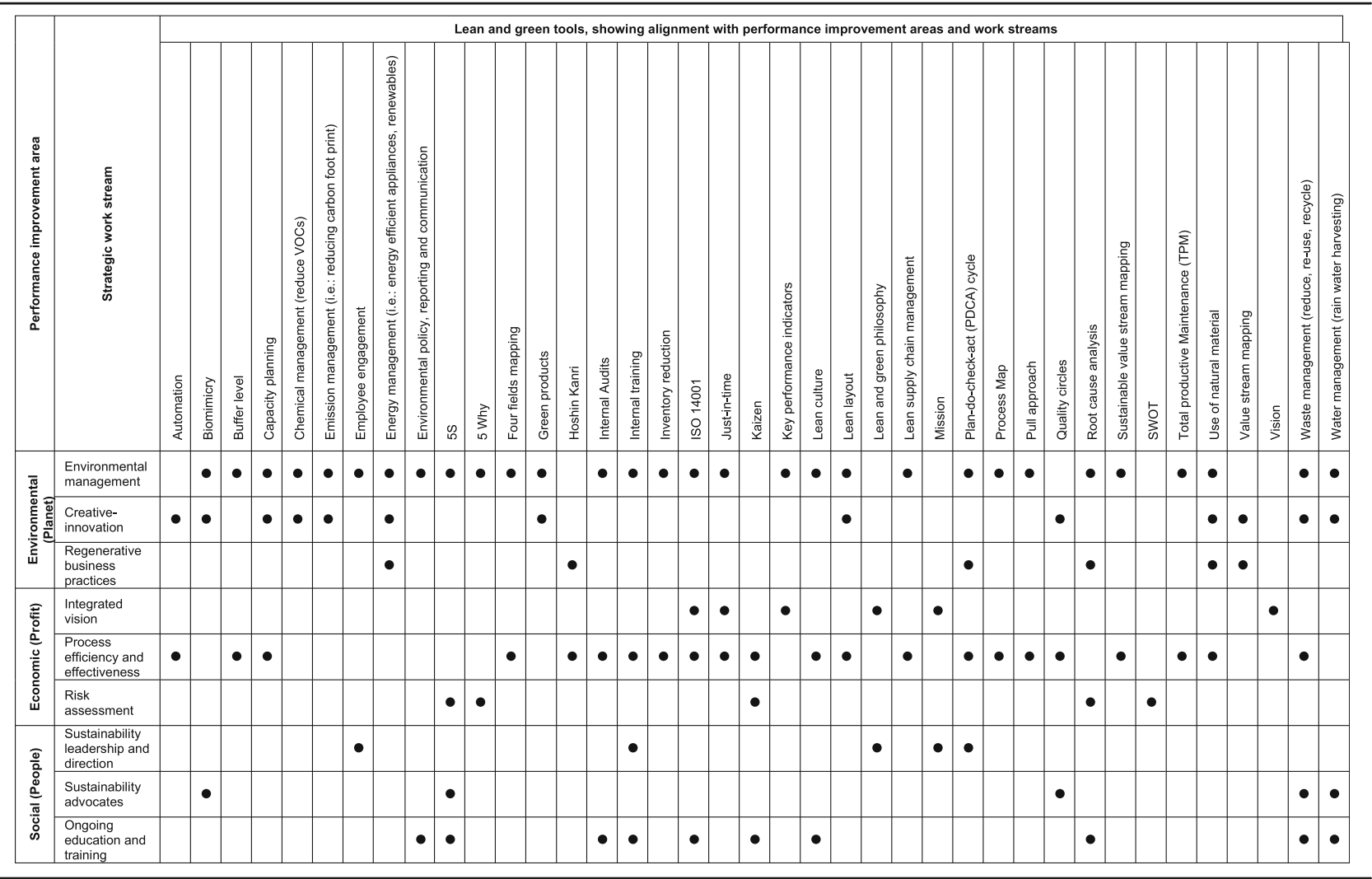

analysis and select the most beneficial and cost-effective set of tools.

Respondents across both SMEs discussed journeys of incremental change through investing in appropriate lean practices to minimise waste and increase efficiency in manufacturing processes. For example, FA-P2 commented, "Our dry manufacturing plant was built with a lot of lean principles built into it. Quality is already in it. The speed, efficiency of the machinery was considered from the beginning". Through this planning Firm A, invested in tools such as lean layout, 5S and capacity planning which were critical tools for their circumstance of building the dry manufacturing plant.

There are a variety of lean tools readily available to SME industrial practitioners looking to harness best outcomes in sustainable business practice. Of the 40 lean tools identified in Table 7, 5S, quality circles, PDCA cycles, internal training, internal auditing and green tools/ concepts such biomimicry, waste and water management can be strategically used along all three performance improvement areas. There is a myriad of tools to support environmental management, creative innovation, process efficiency and effectiveness; out of 40 tools, 35 tools are useful in influencing environmental performance. PDCA cycle is a key problem-solving tool used in lean manufacturing and also a key principle in adhering to ISO
9001 (Quality Management System) and ISO 14001 (Environmental Management System). The $5 \mathrm{~S}$ tool is the most widely used and the most prominent as a starting point for many SMEs in their lean and green journey. However, where $5 \mathrm{~S}$ is used in conjunction with environmental management practices, it can result in cumulative benefits in both operational and environmental management.

There are 28 lean and green tools influencing economic performance. Among those tools, the pull system was valued as an effective tool for reducing inventory waste and improving process efficiency. Within the ten lean and green tools that impacted the social performance of $5 \mathrm{~S}$, internal audits and training played a key role in ongoing awareness and advocating sustainability.

\section{Step 4. Monitor and evaluate towards sustainable business practice}

Finally, SMEs need to monitor and evaluate the performance of the implemented lean and green tools, across desired environmental, social and economic outcomes. This model can be used as an iterative process for continuously addressing strategic work areas (see Fig. 2) through systematically trialling and integrating tools in a customised approach to improvement. In the two case studies the senior decision makers emphasized how 
this model should be an iterative process inspired by the PDCA cycle. For example, as noted by FB-P4, "PDCA cycle which is the continuous improvement cycle it allows people to Plan do check and act".

Senior decision makers of Firm A did monitor and evaluate the usefulness of a procedural structure that enables better decisions and efficient use of resources to achieve environmental performance goals. For example, FA-P1 subscribed the importance of structure, and values structure: "And $5 S$ is part of that discipline, which is required to work as efficient and effective as possible. Also, we are cautious about too much structure, or the limitations caused by it. It imposes on people, life, on creativity, on abundance. We are always monitoring very carefully." This type of structural modifications induce creative innovation in this organization.

Considering the model and matrix in light of outward facing communications with government and the public, they provide a useful framework for prioritising and reporting against progress towards environmental and social benchmarks such as the UN SDGs. By incorporating lean and green thinking within business as usual will enable SMEs to advance their efforts in responsible production which will enable them to advocate resource and energy efficiency, sustainable infrastructure, and improve the quality of life of employees. Implementation of lean and green activities will strengthen the economic competitiveness and attract funding/ aids from professional bodies and government.

With this customised integration of lean and green tools, SMEs can overcome the challenge of ad hoc use of tools and facilitate their enterprises to identify where and how many of these tools can be used to better harness sustainable business outcomes. SMEs have opportunities to become leaner and greener through reducing waste, recycling towards more sustainable production achievement. This research is adds to the evidence base of using lean and green actions together by [25], where a framework for Lean and Green management was provided with associated indicators. Previous research presented a Lean and Green House with accessible procedures to foster synergistic Lean and Green implementation in manufacturing firms [37]. The summarised suite of tools can assist SMEs to strategically select the appropriate lean and green tools according to their business priorities and aspirations.

\section{Conclusions}

This article provides a model and matrix informed by empirical evidence, for strategic use of lean and green practices, which are generally underutilised within SMEs. The findings include eight key drivers that influence SMEs' capacity to engage in sustainable business practice, with predominantly normative drivers observed. The authors presented the first 3P Model for lean and green strategy, comprising four steps that SMEs can follow, and including a 3P matrix of tools to selectively engage with lean and green actions towards sustainable business practice. The model and matrix have the potential to improve SMEs' engagement in environmental, economic and social activities, and accumulate resources to engage in natural-resource-based view strategies of pollution prevention, product stewardship and sustainable development.

It is important to note that the study sample is limited to SMEs in South East Queensland. Within this geographical region there were notable unique contextual drivers that influence sustainable business practice adoption for SMEs (e.g. the unique market and local and state government regulatory environment). However, these examples were not intended to be exhaustive. The findings of the two case studies may not be generalizable across other contexts from participants or cases were drawn. The purpose of conducting these interpretive case studies was to draw on unique examples of SMEs modelling sustainable business practice and generate rich contextualised insights.

To ensure rigour in the interpretive research method, the strategies such as providing a clear chain of evidence, using alternative explanations and corroborating findings were used. It is acknowledged that this research has limitations due to its qualitative nature and lacks quantitative analysis to minimize subjectivity. While these case studies help to establish guidelines, the next step would be to quantitatively test and analyse the Lean and green strategy model in different industries and also conduct field experiments to determine the level of influence that lean and green tools have on sustainable business practice. The role of lean and green thinking is critical for sustainability transformation, as explained through the theoretical lenses of Institutional mechanisms and NRBV strategies. These findings provide practical guidelines to enable SMEs to pursue sustainable business practice aligned with triple bottom line approach where SMEs can simultaneously value their achievements in three dimensions: people, planet and profit (3Ps). The findings also have immediate policy and governance implications within the public and private sector, providing guidance on integrating lean and green thinking to advance from doing 'business as usual'.

\section{Additional file}

Additional file 1: Interview guide. (DOCX 17 kb)

Abbreviations

5S: Sort, Set in order, Shine, Standardise, Sustain; ABS: Australian Bureau of Statistics; CEO: Chief Executive Officer; JIT: Just-In-Time; MD: Managing

Director; MSDS: Material Safety Data Sheet; NASAA: National Association for Sustainable Agriculture, Australia; NRBV: Natural Resource-Based View; PDCA Cycle: Plan, Do, Check, Act cycle; SDGs: Sustainable Development Goals; 
SME: Small and Medium-sized Enterprise; UN: United Nations; VOC: Volatile Organic Compound; VSM: Value Stream Mapping

\section{Acknowledgements}

We acknowledge the support of the QUT Academic Language and Learning Service, in particular Karyn Gonano, in reviewing the academic writing of this article.

\section{Funding}

This research was undertaken as part of a QUT funded PhD Scholarship.

\section{Availability of data and materials}

The datasets generated and analysed during the current study are not publicly available due confidentiality and ethical concerns but are available from the corresponding author on reasonable request.

\section{Authors' contributions}

HTSC undertook the literature review, analysis and interpretation of the data. CD and LD reviewed and contributed to the editing of the manuscript. All authors read and approved the final manuscript.

\section{Authors' information}

Dr. Savindi Caldera: Savindi Caldera is a Research Fellow at the Cities, Research Institute, Griffith University, Brisbane, Australia. Savindi completed her PhD on lean and green manufacturing at Queensland University of Technology, Australia in May 2018. She has been working with colleagues to build capacity for lean and green thinking, resource efficiency and sustainable business practice, to foster a resilient natural and built environments. Her research focuses on developing pragmatic approaches to increase SMEs' contribution towards sustainable development. She has industrial experience as a sustainability specialist in the manufacturing industry in Australia and overseas. Associate Professor Cheryl Desha: Cheryl Desha is an Associate Professor and Head of Civil Engineering at Griffith University Brisbane, Australia (Adjunct Associate Professor at Queensland University of Technology, Brisbane) responsible for designing and delivering an unprecedented 'twenty-first Century' civil engineering curriculum and has been working to build capacity for sustainable development. She has co-authored more than 119 publications including 7 books, 2 of which have been listed in the top 40 publications by the Cambridge Institute for Sustainability Leadership.

Professor Les Dawes: Les Dawes is a Professor in Civil and Environmental Engineering at the Civil Engineering and Built Environment School Queensland University of Technology. He is also Discipline Leader for Environmental Systems and Editor in Chief for the Australasian Journal of Engineering Education. Prof Dawes' research has focused on developing a better understanding of natural systems, both land and water related. His research is application based and grounded in finding solutions to complex environmental problems.

\section{Ethics approval and consent to participate}

All procedures performed in studies involving human participants were in accordance with the ethical standards of the institutional and national research committee and with the 1964 Helsinki declaration and its later amendments or comparable ethical standards. Formal ethical clearance (QUT Ethics Approval Number: 1500000783) was obtained from the QUT human research ethics committee to undertake the interviews supporting the multiple case study.

\section{Consent for publication}

Not applicable.

\section{Competing interests}

The authors declare that they have no competing interests.

\section{Publisher's Note}

Springer Nature remains neutral with regard to jurisdictional claims in published maps and institutional affiliations.

\section{Author details}

'School of Earth, Environmental and Biological Sciences, Science and Engineering Faculty, Queensland University of Technology (QUT), 2-George Street, Brisbane, QLD 4001, Australia. ${ }^{2}$ Cities Research Institute, Griffith University, 170 Kessels Road, Nathan, QLD 4111, Australia. ${ }^{3}$ School of Civil Engineering and Built Environment, Science and Engineering Faculty,
Queensland University of Technology (QUT), 2-George Street, Brisbane, QLD 4001, Australia.

Received: 1 September 2018 Accepted: 21 March 2019

Published online: 15 April 2019

\section{References}

1. Elkington J. Partnerships from cannibals with forks: the triple bottom line of 21st-century business. Environ Qual Manag. 1998;8:37-51.

2. Australian Bureau of Statsitics. Australian and New Zealand Standard Industrial Classification (ANZSIC) [http://www.abs.gov.au/ausstats/abs@.nsf/ mf/1292.0.55.002] Accessed 15 Jan 2016

3. Womack JP, Jones DT. Lean thinking: banish waste and create wealth in your organisation. New York: Simon and Shuster; 1996. p. 397.

4. Hines P. Lean and green. Source Magazine The Home of Lean Thinking. 2009.

5. Revell A, Stokes D, Chen H. Small businesses and the environment: turning over a new leaf? Bus Strateg Environ. 2010;19:273-88.

6. Hillary R. Small and medium-sized enterprises and the environment: business imperatives: Greenleaf Publishing; 2000. https://trove.nla.gov.au/ work/35183863?q\&versionld=43712340.

7. Jovane F, Yoshikawa H, Alting L, Boër C, Westkamper E, Williams D, Tseng $M$, Seliger $G$, Paci A. The incoming global technological and industrial revolution towards competitive sustainable manufacturing. CIRP Ann-Manuf Technol. 2008;57:641-59.

8. Von Weizsacker EU, Hargroves C, Smith MH, Desha C, Stasinopoulos P. Factor five : transforming the global economy through $80 \%$ improvements in resource productivity. Hoboken: Routledge; 2009.

9. Transforming out world: The 2030 Agenda for SustainableDevelopment [https://sustainabledevelopment.un.org/?menu=1300] Accessed 15 Jan 2016.

10. Manda BK. Application of life cycle assessment for corporate sustainability: integrating environmental sustainability in business for value creation: Uitgeverij BOXPress; 2014. https://www.narcis.nl/publication/RecordID/oai: dspace.library.uu.nl:1874\%2F306314.

11. Lawrence SR, Collins E, Pavlovich K, Arunachalam M. Sustainability practices of SMEs: the case of NZ. Bus Strateg Environ. 2006;15:242-57.

12. Caldera H, Desha C, Dawes L. Exploring the characteristics of sustainable business practice in small and medium-sized enterprises: experiences from the Australian manufacturing industry. J Clean Prod. 2018;177:338-49.

13. Verboven $H$, Vanherck L. Sustainability management of SMEs and the UN Sustainable Development Goals. uwf UmweltWirtschaftsForum. 2016;24:165-78.

14. Williamson D, Lynch-Wood G, Ramsay J. Drivers of environmental behaviour in manufacturing SMEs and the implications for CSR. J Bus Ethics. 2006;67: 317-30.

15. Deif AM. A system model for green manufacturing. J Clean Prod. 2011;19: 1553-9.

16. Henriques J, Catarino J. Sustainable value and cleaner production - research and application in 19 Portuguese SME. J Clean Prod. 2015;96:379-86.

17. Van Berkel R. Cleaner production and eco-efficiency initiatives in Western Australia 1996-2004. J Clean Prod. 2007;15:741-55.

18. Côté R, Booth A, Louis B. Eco-efficiency and SMEs in Nova Scotia, Canada. J Clean Prod. 2006;14:542-50.

19. Suh S, Lee KM, Ha S. Eco-efficiency for pollution prevention in small to medium-sized enterprises: a case from South Korea. J Ind Ecol. 2005;9:223-40.

20. Fernández-Viñé MB, Gómez-Navarro T, Capuz-Rizo SF. Assessment of the public administration tools for the improvement of the eco-efficiency of small and medium sized enterprises. J Clean Prod. 2013:47:265-73.

21. Womack JP, Jones DT. Lean thinking: banish waste and create wealth in your corporation: Simon and Schuster; 2010. http://librarycatalogue.griffith. edu.au/record=b1617090.

22. Hines $\mathrm{P}$, Holwe $\mathrm{M}$, Rich $\mathrm{N}$. Learning to evolve: a review of contemporary lean thinking. Int J Oper Prod Manag. 2004;24:994-1011.

23. Ōno T. Toyota production system: beyond large-scale production: Productivity press; 1988. http://librarycatalogue.griffith.edu.au/record= b1546822.

24. Caldera HTS, Desha C, \& Dawes L. Evaluating the enablers and barriers for successful implementation of sustainable business practice in 'lean' SMEs. Journal of Cleaner Production. 2019;218:575-90. doi: https://doi.org/10.1016/ j.jclepro.2019.01.239. 
25. Verrier B, Rose B, Caillaud E, Remita H. Combining organizational performance with sustainable development issues: the lean and green project benchmarking repository. J Clean Prod. 2014;85:83-93.

26. Thanki S, Govindan K, Thakkar J. An investigation on lean-green implementation practices in Indian SMEs using analytical hierarchy proces (AHP) approach. J Clean Prod. 2016;135:284-98.

27. Dhingra R, Kress R, Upreti G. Does lean mean green? J Clean Prod. 2014;85:1-7.

28. Chiarini A. Sustainable manufacturing-greening processes using specific lean production tools: an empirical observation from European motorcycle component manufacturers. J Clean Prod. 2014;85:226-33.

29. King AA, Lenox MJ. Lean and green? An empirical examination of the relationship between lean production and environmental performance. Prod Oper Manag. 2001;10:244-56.

30. Dües CM, Tan KH, Lim M. Green as the new lean: how to use lean practices as a catalyst to greening your supply chain. J Clean Prod. 2013;40:93-100.

31. Galeazzo A, Furlan A, Vinelli A. Lean and green in action: interdependencies and performance of pollution prevention projects. Clean Prod. 2014;85:191-200.

32. Amani P, Lindbom I, Sundström B, Östergren K. Green-lean synergy-rootcause analysis in food waste prevention. Int J Food Syst Dyn. 2015;6:99-109.

33. Gibson I, Yoke San W, Pham D, Pham P, Thomas A. Integrated production machines and systems-beyond lean manufacturing. J Manuf Technol Manag. 2008;19:695-711.

34. Garza-Reyes JA. Lean and green - a systematic review of the state of the art literature. J Clean Prod. 2015;102:18-29.

35. Caldera HTS, Desha C, \& Dawes L. Exploring the characteristics of sustainable business practice in small and medium-sized enterprises: Experiences from the Australian manufacturing industry. Journal of Cleaner Production. 2018;177:338-49. https://www.sciencedirect.com/science/article/ pii/S0959652617332596.

36. Martínez León HC, Calvo-Amodio J. Towards lean for sustainability: Understanding the interrelationships between lean and sustainability from a systems thinking perspective. J Cleaner Prod. 2017;142(Part 4):4384-402.

37. Verrier B, Rose B, Caillaud E. Lean and green strategy: the lean and green house and maturity deployment model. J Clean Prod. 2016;116:150-6.

38. Bhanot N, Rao PV, Deshmukh S. An integrated approach for analysing the enablers and barriers of sustainable manufacturing. J Clean Prod. 2017;142:4412-39.

39. Prabawani B. Measuring SMEs' sustainability: a literature review and agenda for research. Int J Manag Sustain. 2013;2:193-207.

40. Simpson M, Taylor N, Barker K. Environmental responsibility in SMEs: does it deliver competitive advantage? Bus Strateg Environ. 2004;13:156-71.

41. Cagno E, Trianni A, Spallina G, Marchesani F. Drivers for energy efficiency and their effect on barriers: empirical evidence from Italian manufacturing enterprises. Energ Effic. 2017;10:855-69.

42. Geng Y, Doberstein B. Developing the circular economy in China: challenges and opportunities for achieving'leapfrog development'. Int I Sust Dev World Ecology. 2008;15:231-9.

43. Stahel WR. Circular economy. Nature. 2016;531(7595):435-38. http://search. proquest.com.libraryproxy.griffith.edu.au/docview/1776790666?accountid=14543.

44. Caldera HTS, Desha C, Dawes L. Evaluating SMEs' relationships with 'lean' and 'green' thinking when aiming for sustainable business practice. In: In Proceedings of 18th European Rountable for Sustainable Consumption and Production Skiathos Island, Greece; 2017.

45. Dhingra R, Das $S$, Kress R. Making progress towards more sustainable societies through lean and green initiatives. J Clean Prod. 2012;37:400-2.

46. Upadhye N, Deshmukh SG, Garga S. Lean manufacturing for sustainable development. Glob Bus Manag Res. 2010;2:125-37.

47. Hong P, James Jungbae R, Rawski G. Benchmarking sustainability practices: evidence from manufacturing firms. Benchmarking. 2012;19:634-48.

48. Piercy $\mathrm{N}$, Rich $\mathrm{N}$. The relationship between lean operations and sustainable operations. Int J Oper Prod Manag. 2015;35:282.

49. Wu L, Subramanian N, Abdulrahman MD, Liu C, Lai KH, Pawar KS. The impact of integrated practices of lean, green, and social management systems on firm sustainability performance-evidence from Chinese fashion auto-parts suppliers. Sustainability. 2015;7:3838-58.

50. Aguado S, Alvarez R, Domingo R. Model of efficient and sustainable improvements in a lean production system through processes of environmental innovation. J Clean Prod. 2013:47:141-8.
51. Klein HK, Myers MD. A set of principles for conducting and evaluating interpretive field studies in information systems. MIS Q. 1999;23:67-93.

52. Walsham G. Doing interpretive research. Eur J Inf Syst. 2006;15:320-30.

53. Caldera HT. Doing more with less: exploring approaches to sustainable business practice in small and medium-sized enterprises (SMEs): Queensland University of Technology; 2018. https://eprints.qut.edu.au/118728/.

54. Patton MQ. Qualitative evaluation and research methods: SAGE Publications, inc; 1990. https://psycnet.apa.org/record/1990-97369-000

55. Flyvbjerg B. Five misunderstandings about case-study research. Qual Inq. 2006;12:219-45.

56. Cassell C, Symon G. Taking qualitative methods in organization and management research seriously. Qual Res Org Manag: An International Journal. 2006;1:4-12

57. Rubin HJ, Rubin IS. Qualitative interviewing: the art of hearing data: Sage; 2011. https://books.google.com.au/books?isbn=1452280029.

58. Yin RK. Case study research: design and methods: Sage publications; 2013.

59. Yin RK. Case study research: design and methods. Sage Pub: Thousand Oaks; 2009.

60. Bazeley P, Jackson K. Qualitative data analysis with NVivo: Sage Publications Limited; 2013. https://books.google.com.au/books?isbn=1446282473.

61. Miles MB, Huberman AM. Qualitative data analysis: An expanded sourcebook: Sage; 1994. p. 1994. https://books.google.com.au/books?isbn= 0803955405.

62. Bandara W: Using Nvivo as a research management tool: A case narrative. In Quality and Impact of Qualitative Research: Proceedings of the 3rd International Conference on Qualitative Research in IT \& IT in Qualitative Research. 2006.

63. Glaser BG, Strauss AL. The discovery of grounded theory: strategies for qualitative research: Transaction publishers; 2009. https://books.google.com. au/books?isbn=0202363376.

64. King A. In vivo coding. The SAGE encyclopedia of qualitative research methods; 2008. p. 473-4.

65. Savin-Baden M, Major CH. Qualitative research: the essential guide to theory and practice. Milton Park: Routledge; 2013.

66. Fram SM. The constant comparative analysis method outside of grounded theory. Qual Rep. 2013;18:1-25.

67. Lee TW. Using qualitative methods in organizational research: Sage; 1999. https://books.google.com.au/books?isbn=0761908072.

68. Braun V, Clarke V. Using thematic analysis in psychology. Qual Res Psychol. 2006;:37-101.

69. Creswell JW. Research design: qualitative, quantitative, and mixed methods approaches: Sage publications; 2013. https://books.google.com.au/ books?isbn=1483321479.

70. Walsham G. Interpretive case studies in IS research: nature and method. Eur J Inf Syst. 1995;4:74-81.

71. Strauss AL, Corbin JM. Grounded theory: Grundlagen qualitativer sozialforschung; 1996.

72. Seidel S, Recker JC, Vom BJ. Sensemaking and sustainable practicing: functional affordances of information systems in green transformations. Manag Inf Syst Q. 2013;37:1275-99.

73. Eisenhardt KM. Building theories from case study research. Acad Manag Rev. 1989;14:532-50.

74. Pettigrew AM. Longitudinal field research on change: theory and practice. Organ Sci. 1990;1:267-92.

75. Silverman D. Doing qualitative research. Thousand Oaks: SAGE; 2013.

76. Campbell JL, Quincy C, Osserman J, Pedersen OK. Coding in-depth semistructured interviews: problems of unitization and intercoder reliability and agreement. Sociol Methods Res. 2013;42:294-320.

77. Lombard M, Snyder-Duch J, Bracken CC. Content analysis in mass communication: assessment and reporting of intercoder reliability. Hum Commun Res. 2002;28:587-604

78. Berke PR, Conroy MM. Are we planning for sustainable development? An evaluation of 30 comprehensive plans. J Am Plan Assoc. 2000;66:21-33.

79. Gregor S. The nature of theory in information systems. MIS Quarterly. 2006; 30(3):611-42. https://www.jstor.org/stable/25148742? seq=1\#metadata_info_ tab_contents.

80. Elkington J. Triple bottom line revolution: reporting for the third millennium. Australian CPA. 1999;69:75-6.

81. DiMaggio PJ, Powell $\mathrm{WW}$. The Iron cage revisited: institutional isomorphism and collective rationality in organizational fields. Am Sociol Rev. 1983;48:147-60. 
82. Kilbourne WE, Beckmann SC, Thelen E. The role of the dominant socia paradigm in environmental attitudes: a multinational examination. J Bus Res. 2002;55:193-204.

83. Glover JL, Champion D, Daniels KJ, Dainty AJD. An institutional theory perspective on sustainable practices across the dairy supply chain. Int J Prod Econ. 2014;152:102-11.

84. Hart SL. A natural-resource-based view of the firm. Acad Manag Rev. 1995; 20:986-1014.

85. Aragón-Correa JA, Hurtado-Torres N, Sharma S, García-Morales VJ. Environmental strategy and performance in small firms: a resource-based perspective. J Environ Manag. 2008;86:88-103.

86. Triguero A, Moreno-Mondéjar L, Davia MA. Drivers of different types of ecoinnovation in European SMEs. Ecol Econ. 2013;92:25-33.

87. Walker B, Redmond J, Sheridan L, Wang C, Goeft U. Small and medium enterprises and the environment: barriers, drivers, innovation and best practice: a review of the literature; 2008.

88. Thomas A, Francis M, John E, Davies A. Identifying the characteristics for achieving sustainable manufacturing companies. J Manuf Technol Manag. 2012;23:426-40.

89. Manzouri M, Ab-Rahman MN, Zain CRCM, Jamsari EA. Increasing production and eliminating waste through lean tools and techniques for halal food companies. Sustainability. 2014;6:9179-204.

90. Vais A, Miron V, Pedersen M, Folke J. "Lean and green" at a Romanian secondary tissue paper and board mill - putting theory into practice. Resour Conserv Recycl. 2006;46:44-74.

91. Thomas A, Barton R, Chuke-Okafor C. Applying lean six sigma in a small engineering company - a model for change. J Manuf Technol Manag. 2008; 20:113-29.

92. Miller G, Pawloski J, Standridge CR. A case study of lean, sustainable manufacturing. J Ind Eng Manag. 2010;3:11-32.

93. Jamian R, Ab Rahman MN, Deros BM, Ismail NZN. A conceptual model towards sustainable management system based upon 5 s practice for manufacturing SMEs. Asia Pac J Oper Manag. 2012;1:19-31.

94. Carvalho H, Duarte S, Cruz MV. Lean, agile, resilient and green: divergencies and synergies. Int J Lean Six Sigma. 2011;2:151-79.

95. Stenzel J. Lean accounting: best practices for sustainable integration: Wiley; 2008. https://books.google.com.au/books?isbn=0470173750.

96. Maia LC, Alves AC, Leão CP. Sustainable work environment with lean production in textile and clothing industry. Int J Ind Eng Manag. 2013:4:183-90.

97. Zokaei K, Lovins H, Wood A, Hines P. Creating a lean and green business system: techniques for improving profits and sustainability: Productivity Press; 2016. https://books.google.com.au/books?isbn=1466571136.

98. Averill D. Lean sustainability: creating safe, enduring, and profitable operations: Productivity Press; 2016. https://books.google.com.au/ books?isbn=1439895295

99. Rother M, Shook J. Learning to see: value stream mapping to add value and eliminate muda: Lean Enterprise Institute; 2003. https://books.google.com. au/books?isbn=0966784308.

100. Tapping D, Luyster T, Shuker T. Value stream management: eight steps to planning, mapping, and sustaining lean improvements: Productivity Press; 2002 https://books.google.com.au/books?isbn=1563272458.

101. Faulkner W, Badurdeen F. Sustainable value stream mapping (Sus-VSM): methodology to visualize and assess manufacturing sustainability performance. J Clean Prod. 2014;85:8-18.

102. Rahani A, Al-Ashraf M. Production flow analysis through value stream mapping: a lean manufacturing process case study. Procedia Engineering. 2012:41:1727-34

103. Hines P, Rich N, Bicheno J, Brunt D, Taylor D, Butterworth C, Sullivan J. Value stream management. Int J Logist Manag. 1998;9:25-42.

104. Helleno AL, de Moraes AJl, Simon AT. Integrating sustainability indicators and lean manufacturing to assess manufacturing processes: application case studies in Brazilian industry. J Clean Prod. 2017;153:405-16.

105. Kurdve M, Zackrisson M, Wiktorsson M, Harlin U. Lean and green integration into production system models - experiences from Swedish industry. J Clean Prod. 2014;85:180-90.

106. Wong WP, Wong KY. Synergizing an ecosphere of lean for sustainable operations. J Clean Prod. 2014;85:51-66.

\section{Ready to submit your research? Choose BMC and benefit from:}

- fast, convenient online submission

- thorough peer review by experienced researchers in your field

- rapid publication on acceptance

- support for research data, including large and complex data types

- gold Open Access which fosters wider collaboration and increased citations

- maximum visibility for your research: over $100 \mathrm{M}$ website views per year

At $\mathrm{BMC}$, research is always in progress.

Learn more biomedcentral.com/submissions 